\title{
Superficial siderosis of the central nervous system is a rare and possibly underdiagnosed disorder
}

\author{
Siderose superficial do sistema nervoso central é uma doença rara e possivelmente \\ subdiagnosticada
}

\author{
Yara Dadalti Fragoso', Tarso Adoni², Joseph Bruno Bidin Brooks', Sidney Gomes³, Marcus Vinicius Magno \\ Goncalves ${ }^{4}$, Cassio Lemos Jovem ${ }^{5}$, Andre Palma da Cunha Matta ${ }^{6}$, Joao Filipe Oliveira ${ }^{7}$, Fabio Siquinelli \\ Carlos Bernardo Tauil ${ }^{8}$, Guilherme Navarro Troiani', Paulo Roberto Wille ${ }^{9}$
}

\begin{abstract}
Superficial siderosis (SS) of the central nervous system (CNS) is a rare and possibly underdiagnosed disorder resulting from chronic or intermittent bleeding into the subarachnoid space, leading to deposition of blood products in the subpial layers of the meninges. Magnetic resonance imaging (MRI) shows a characteristic curvilinear pattern of hypointensity on its blood-sensitive sequences. Methods: Series of cases collected from Brazilian centers. Results: We studied 13 cases of patients presenting with progressive histories of neurological dysfunction caused by SS-CNS. The most frequent clinical findings in these patients were progressive gait ataxia, hearing loss, hyperreflexia and cognitive dysfunction. The diagnoses of SS-CNS were made seven months to 30 years after the disease onset. Conclusion: SS-CNS is a rare disease that may remain undiagnosed for long periods. Awareness of this condition is essential for the clinician.
\end{abstract}

Keywords: siderosis; brain; hearing loss; ataxia.

\begin{abstract}
RESUMO
Siderose superficial (SS) do sistema nervoso central (SNC) é uma doença rara e provavelmente subdiagnosticada, resultante de sangramento crônico no espaço subaracnóide, levando ao depósito de produtos sanguíneos nas camadas meníngeas subpiais. Ressonância magnética (RM) mostra um padrão curvilíneo característico com hipointensidade nas suas sequências sensíveis a sangue. Métodos: Série de casos coletados de centros brasileiros. Resultados: Apresentamos 13 casos de pacientes com história progressiva de disfunção neurológica causada por SS-SNC. Os achados clínicos mais frequentes destes pacientes foram ataxia progressiva da marcha, perda auditiva, hiperreflexia e disfunção cognitiva. O diagnóstico de SS-SNC foi firmado de sete meses a 30 anos após o início da doença. Conclusão: SS-SNC é uma condição rara que pode permanecer sem diagnóstico por longos períodos. O conhecimento desta entidade é essencial ao clínico.
\end{abstract}

Palavras-chave: siderose; encéfalo; perda auditiva; ataxia.

Superficial siderosis (SS) of the central nervous system (CNS) was described over 100 years ago as "melanosis of the brain". This rare disorder results from chronic or intermittent bleeding into the subarachnoid space, leading to deposition of blood byproducts in the subpial layers of the meninges 2 . The presence of hemoglobin will lead to synthesis of ferritin and hemosiderin, resulting in proliferation of microglia and neuronal injury in the area ${ }^{3}$. Although a variety of unspecific symptoms may be present in some patients, it is the adult onset of progressive neurosensory hearing loss, gait ataxia and pyramidal dysfunction that ultimately suggests SS-CNS as a potential diagnosis ${ }^{4}$. Other manifestations include dementia, sphincter dysfunction, anosmia, anisocoria and sensory signs. Less frequent features include extra-ocular motor palsies; head, neck or backache; bilateral sciatica; and lower motor neuron signs.

\footnotetext{
'Universidade Metropolitana de Santos, Departamento de Neurologia, Santos SP, Brasil;

${ }^{2}$ Hospital Sirio-Libanes, Departamento de Neurologia, São Paulo SP, Brasil;

${ }^{3}$ Hospital Beneficência Portuguesa e Hospital Paulistano, Departamento de Neurologia, São Paulo SP, Brasil;

${ }^{4}$ Centro Hospitalar Unimed, Departamento de Neurologia, Joinville SC, Brasil;

${ }^{5}$ Hospital de Base do Distrito Federal, Departamento de Radiologia, Brasília DF, Brasil;

${ }^{6}$ Universidade Federal Fluminense, Departamento de Neurologia, Niterói RJ, Brasil;

${ }^{7}$ Universidade Regional de Blumenau, Departamento de Neurologia, Blumenau SC, Brasil;

${ }^{8}$ Hospital de Base do Distrito Federal, Departamento de Neurologia, Brasília DF, Brasil;

${ }^{9}$ IdHera, Departamento de Neurorradiologia, Joinville SC, Brasil.
}

Correspondence: Yara Dadalti Fragoso; Departamento de Neurologia, Faculdade de Medicia, UNIMES; Rua da Constituição, 374 ; 11015 -470 Santos SP, Brasil; E-mail:yara@bsnet.com.br

Conflict of interest: There is no conflict of interest to declare.

Received 31 May 2016; Received in final form 13 November 2016; Accepted 16 November 2016. 
A prior history of trauma or surgical procedures may be found in the patient's history ${ }^{5,6}$. The time that elapses between the bleeding episode (if this is identified at all) and the onset of symptoms varies between months and years. Clinical and surgical treatments of SS-CNS are often ineffective and the disease progresses slowly and inexorably. Although deferiprone ${ }^{7}$ and cochlear implants ${ }^{8}$ have been tried, a successful form of therapy continues to be sought.

Magnetic resonance imaging(MRI) is essential for confirming the diagnosis of SS-CNS. It shows a characteristic curvilinear pattern of hypointensity on blood-sensitive MRI sequences, reflecting blood residues in the subpial layers of the cerebral cortex or in the subarachnoid space ${ }^{2}$. The magnetic susceptibility effects of blood degradation products are more pronounced at high field strength ${ }^{2,6}$. It is important to recognize that initial signs of ferritin and hemosiderin deposition can be very subtle and unless the radiologist is well aware of this potential diagnosis, the examination may be reported as being normal'. On the other hand, abnormal MRI results may be present in the absence of symptoms of SS ${ }^{2}$. Around 300 cases of SS-CNS have been reported in the literature, mostly as individual case reports or series of three or four cases. The present study presents a series of 13 cases of SS-CNS that occurred in Brazilian patients, thus making this one of the largest series of original cases in the literature.

\section{METHODS}

Neurologists from seven academic units in Brazil sent complete clinical and imaging data on patients with the diagnosis of SS-CNS. Both primary and secondary cases of blood products accumulation in the CSN were acceptable for the purpose of this paper.

Only cases with full data were included in the report. All images were analyzed by neuroradiologists according to a strict protocol for acceptance for this series of cases.

Table. Summary of data on the patients with siderosis of the central nervous system.

\begin{tabular}{|c|c|c|c|c|c|c|c|}
\hline Patient & Gender & Age & Signs and symptoms & $\begin{array}{l}\text { Duration of } \\
\text { neurological } \\
\text { condition }\end{array}$ & $\begin{array}{l}\text { Previous } \\
\text { bleeding } \\
\text { or trauma }\end{array}$ & Etiology & Main findings on MRI \\
\hline 1 & M & 68 & $\begin{array}{c}\text { Progressive paraparesis and } \\
\text { gait ataxia, hyperreflexia, } \\
\text { hearing loss }\end{array}$ & 3 years & no & unknown & $\begin{array}{l}\text { Hypointensity on T2 around } \\
\text { the brainstem, cerebellum and } \\
\text { spinal cord }\end{array}$ \\
\hline 2 & M & 69 & $\begin{array}{c}\text { Progressive behavioral } \\
\text { disorder }\end{array}$ & 10 months & yes & $\begin{array}{l}\text { Closed head } \\
\text { trauma }\end{array}$ & $\begin{array}{l}\text { Hypointensity on T2 around the } \\
\text { frontal lobe }\end{array}$ \\
\hline 3 & $\mathrm{~F}$ & 65 & $\begin{array}{l}\text { Progressive gait ataxia, } \\
\text { hyperreflexia, hearing loss, } \\
\text { cognitive dysfunction }\end{array}$ & 7 months & no & unknown & $\begin{array}{c}\text { Hypointensity on T2 around } \\
\text { the brainstem, cerebellum } \\
\text { and spinal cord; atrophic } \\
\text { cerebellum }\end{array}$ \\
\hline 4 & M & 71 & $\begin{array}{l}\text { Progressive cognitive } \\
\text { disorder, disorientation, mild } \\
\text { gait ataxia, seizures }\end{array}$ & 2 years & yes & $\begin{array}{l}\text { Hemorrhagic } \\
\text { stroke }\end{array}$ & $\begin{array}{c}\text { Hypointensity on T2 around } \\
\text { the brain, brainstem and } \\
\text { cerebellum }\end{array}$ \\
\hline 5 & $\mathrm{~F}$ & 65 & $\begin{array}{c}\text { Progressive gait ataxia, } \\
\text { dysarthria, hyperreflexia, } \\
\text { hearing loss }\end{array}$ & 3 years & no & unknown & $\begin{array}{l}\text { Multiple epidural hypointense } \\
\text { lesions ("dural tears") }\end{array}$ \\
\hline 6 & M & 48 & $\begin{array}{c}\text { Progressive headache, ataxia, } \\
\text { dysarthria, hyperreflexia, } \\
\text { deafness }\end{array}$ & 30 years & no & unknown & $\begin{array}{l}\text { Brain atrophy and large areas } \\
\text { of hypointensity on } T 2 \text { around } \\
\text { the brain and spinal cord }\end{array}$ \\
\hline 7 & M & 48 & $\begin{array}{c}\text { Dizziness and progressive } \\
\text { hearing loss }\end{array}$ & 7 months & no & unknown & $\begin{array}{c}\text { Brain atrophy, hypointensity on } \\
\text { T2 around the brain }\end{array}$ \\
\hline 8 & M & 71 & $\begin{array}{l}\text { Disorientation and episodic } \\
\text { cognitive deficit }\end{array}$ & 2 years & yes & $\begin{array}{l}\text { Hemorrhagic } \\
\text { stroke }\end{array}$ & $\begin{array}{l}\text { Brain atrophy, gliosis in the } \\
\text { stroke area, hypointensity on T2 } \\
\text { around the brain }\end{array}$ \\
\hline 9 & $\mathrm{~F}$ & 38 & $\begin{array}{l}\text { Dizziness, progressive hearing } \\
\text { loss, gait ataxia, several falls }\end{array}$ & 18 months & yes & $\begin{array}{l}\text { Operated } \\
\text { brain tumor }\end{array}$ & $\begin{array}{c}\text { Gliosis in the tumor area, } \\
\text { hypointensity on T2 around } \\
\text { the brain }\end{array}$ \\
\hline 10 & $\mathrm{~F}$ & 38 & $\begin{array}{c}\text { Dizziness, progressive hearing } \\
\text { loss, gait ataxia, nystagmus, } \\
\text { cognitive dysfunction, } \\
\text { hyperreflexia }\end{array}$ & 3 years & no & unknown & $\begin{array}{c}\text { Hypointensity on T2 around } \\
\text { the brainstem, cerebellum and } \\
\text { spinal cord }\end{array}$ \\
\hline 11 & $\mathrm{~F}$ & 52 & $\begin{array}{l}\text { Progressive paraparesis, } \\
\text { headache, ataxia }\end{array}$ & 30 years & yes & $\begin{array}{l}\text { Post-surgery } \\
\text { to correct } \\
\text { Arnold-Chiari }\end{array}$ & $\begin{array}{l}\text { Hypointensity on } \mathrm{T} 2 \text { around the } \\
\text { brainstem and cerebellum }\end{array}$ \\
\hline 12 & M & 55 & $\begin{array}{c}\text { Progressive gait ataxia and } \\
\text { hearing loss }\end{array}$ & 10 years & yes & $\begin{array}{l}\text { Closed head } \\
\text { trauma }\end{array}$ & $\begin{array}{l}\text { Hypointensity on } \mathrm{T} 2 \text { around the } \\
\text { meninges and brainstem }\end{array}$ \\
\hline 13 & M & 50 & $\begin{array}{c}\text { Progressive gait ataxia, } \\
\text { hyperreflexia, hearing loss, } \\
\text { cognitive dysfunction, } \\
\text { disorientation, headache, } \\
\text { vomiting }\end{array}$ & 2 years & no & unknown & $\begin{array}{c}\text { Hypointensity on T2 around } \\
\text { the brainstem, cerebellum and } \\
\text { spinal cord }\end{array}$ \\
\hline
\end{tabular}

M: male; F: female. 
Reports on the observations were approved by the Ethics Committee. Further approvals from other institutions were obtained whenever required.

Thirteen patients were included in this series (eight men and five women), aged between 38 and 71 years (median age 50 years) at the time of diagnosis.

An MRI was the cornerstone for diagnosing all the cases, and this identified hemosiderin deposition in different areas of the CNS.

\section{RESULTS}

The initial symptoms varied, but the most frequent findings were progressive gait ataxia (10 cases), hearing loss (six cases), hyperreflexia ( five cases) and cognitive or behavioral dysfunction (five cases). All patients presented with progressive onset of signs and symptoms, and received the diagnosis of SS-CNS seven months to 30 years after the disease onset. The episodes leading to accumulation of blood in the CNS of these patients were unidentified in seven cases, brain trauma in two cases, hemorrhagic stroke in two cases and brain surgery in two cases. Whenever the cause for the bleeding was not identified, the patient underwent image examinations for identification of arterial, venous or arterio-venous malformations. No cases of these vascular abnormalities were identified. A summary of all cases is presented in the Table. The Figure shows some characteristic images obtained from these patients.

\section{DISCUSSION}

Superficial siderosis of the CNS is a relatively rare condition that needs to be considered in the differential diagnosis for adults presenting with progressive symptoms of dysfunction of the CNS. The presence of previous episodes leading to bleeding into the CNS is helpful while considering SS-CNS as a differential diagnosis of progressive neurological dysfunction, but it is not essential for the diagnosis itself. The signs and symptoms vary, but gait ataxia, hearing loss, hyperreflexia and cognitive dysfunction were the most common findings among the patients of the present series and in previous reports in the literature ${ }^{9}$. The signs and symptoms were progressive in all our patients, in accordance with the physiopathology of SS-CNS.

An MRI is a very important tool for diagnosis, but the medical team needs to be aware of SS-CNS as a potential diagnosis and inform the radiologist of this possibility. The subtle signs of hemosiderin deposition (hypointensity following the contours of the brain and spinal cord) may easily be missed if the radiologist does not have experience with this rare disease $e^{10}$.
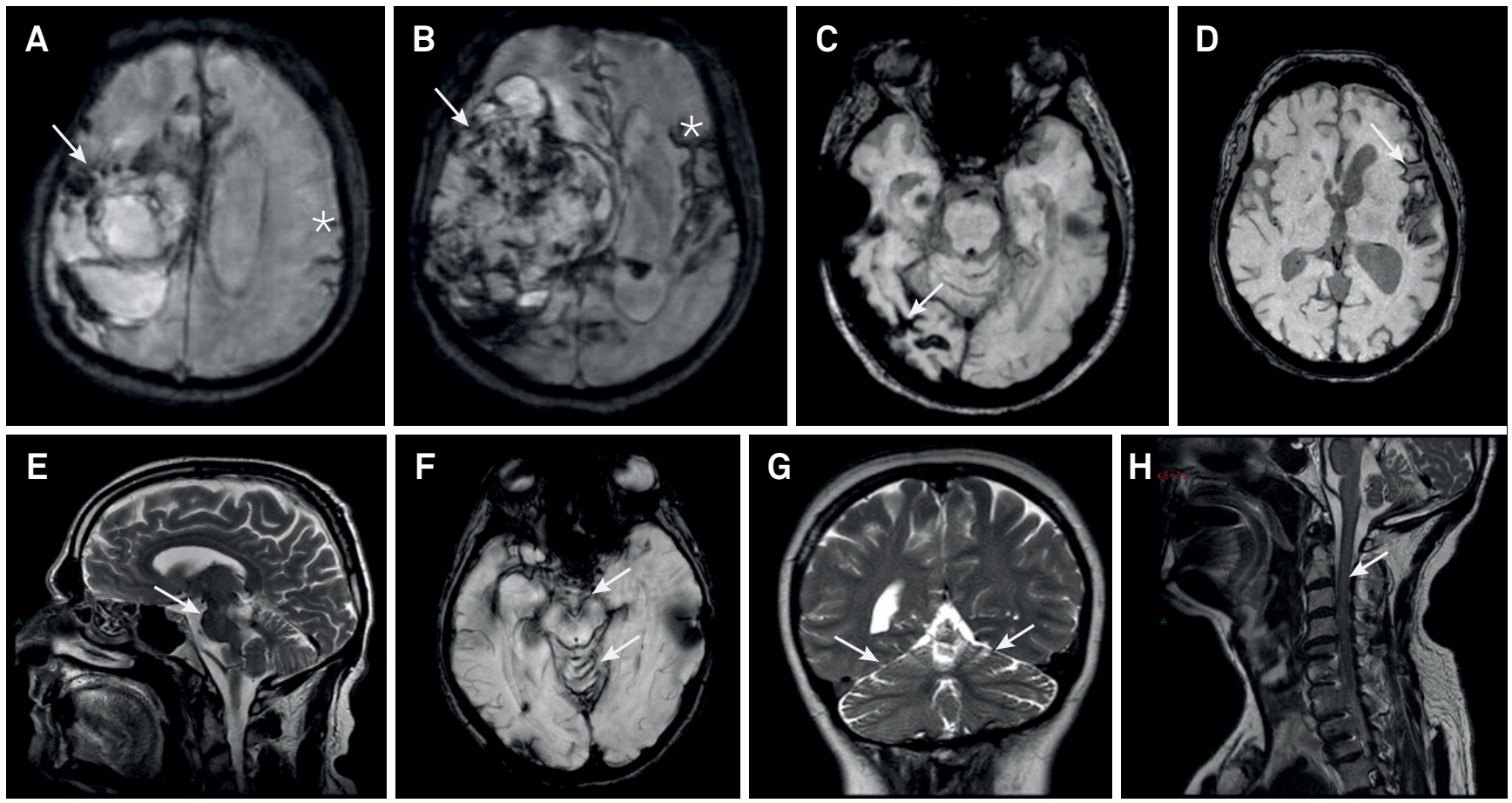

Figure. A and B:T2* MR images are from a patient with a right frontal intracerebral hemorrhage (arrows) and hemosiderin deposit along the left Sylvian fissure and left fronto-parietal sulcis (stars). Images C and D: SWAN images (susceptibility-weighted imaging) T1-weight MR images show hemosiderin deposit along the left Sylvian fissure and right occipital sulcis (arrows). Images $\mathrm{E}$ and $\mathrm{H}$ are T2-weight MR from the same patient showing the typical hypointense layer around the pons and the cervical spinal cord (arrows). F is a T2* MR image showing a hypointense layer around the pons and cerebelar vermis (arrows), while G is a T2- weight MR image from a patient with superficial siderosis associated to severe cerebellar atrophy (arrow). 


\section{References}

1. Hamill RC. Report of a case of melanosis of the brain, cord, and meninges. J Nerv Ment Dis. 1908;35(9):594. http://doi.org/10.1097/00005053-190809000-00027

2. Kumar N. Superficial siderosis: associations and therapeutic implications. Arch Neurol. 2007;64(4):491-6. http://doi.org/10.1001/archneur.64.4.491

3. Koeppen AH, Michael SC, Li D, Chen Z, Cusack MJ, Gibson WM et al. The pathology of superficial siderosis of the central nervous system. Acta Neuropathol. 2008;116(4):371-82. http://doi.org/10.1007/s00401-008-0421-z

4. Posti JP, Juvela S, Parkkola R, Roine S. Three cases of superficial siderosis of the central nervous system and review of the literature. Acta Neurochir (Wien). 2011;153(10):2067-73. http://doi.org/10.1007/s00701-011-1116-0

5. Kumar N, Cohen-Gadol AA, Wright RA, Miller GM, Piepgras DG Ahlskog JE. Superficial siderosis. Neurology. 2006;66(8):1144-52. http://doi.org/10.1212/01.wnl.0000208510.76323.5b
6. Kumar N. Neuroimaging in superficial siderosis: an indepth look. AJNR Am J Neuroradiol. 2010;31(1):5-14. http://doi.org/10.3174/ajnr.A1628

7. Levy M, Llinas R. Pilot safety trial of deferiprone in 10 subjects with superficial siderosis.. Stroke. 2012;43(1):120-4. http://doi.org/10.1161/STROKEAHA.111.628032

8. Wood VH, Bird PA, Giles EC, Baber WJ. Unsuccessful cochlear implantation in two patients with superficial siderosis of the central nervous system. Otol Neurotol. 2008;29(5):622-5. http://doi.org/10.1097/MA0.0b013e3181758e7e

9. Scheid R, Frisch S, Schroeter ML. Superficial siderosis of the central nervous system - treatment with steroids? J Clin Pharm Ther. 2009;34(5):603-5. http://doi.org/10.1111/j.1365-2710.2009.01030.x

10. Gao JG, Zhou CK, Liu JY. Superficial siderosis of the central nervous system: a case report. Exp Ther Med. 2015;9(4):1379-82 http://doi.org/10.3892/etm.2015.2229 